African Crop Science Journal by African Crop Science Society is licensed under a Creative Commons Attribution 3.0 Uganda License. Based on a work at www.ajol.info/ and www.bioline.org.br/cs

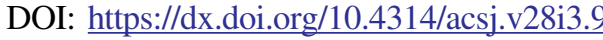

\title{
EFFECT OF SELF-POLLINATION WITH HEAT-TREATED POLLEN ON PARTHENOCARPY AND HOMOZYGOSITY IN CASSAVA
}

\author{
M. BUTTIBWA ${ }^{1,2}$, R.S. KAWUKI ${ }^{2}$, J.K. BAGUMA ${ }^{2}$, P. NALELA ${ }^{2}$, M. EYOKIA ${ }^{2}$, B. OSHABA ${ }^{2}$ \\ H. CEBALLOS ${ }^{3}$, Z. LENTINI ${ }^{4}$, Y. BAGUMA ${ }^{2}$ and A.K. TUGUME \\ ${ }^{1}$ Department of Plant Sciences, Microbiology and Biotechnology, College of Natural Sciences, \\ Makerere University, P. O. Box 7062, Kampala, Uganda \\ ${ }^{2}$ National Crops Resources Research Institute, Namulonge, P. O. Box 7084, Kampala, Uganda \\ ${ }^{3}$ International Center for Tropical Agriculture, Apartado, Aéreo, 6713, Cali, Colombia \\ ${ }^{4}$ Center of Specialized Natural and Biotechnological Ingredients (CINEB), School of Natural \\ Sciences, Universidad ICESI, Cali, Colombia \\ Corresponding author: aktugume@gmail.com
}

(Received 3 June 2020; accepted 29 August 2020)

\begin{abstract}
Cassava's (Manihot esculenta Crantz) high heterozygosity complicates its genetic improvement via selective breeding. Double haploid (DH) technology can be used to improve the crop's heterozygosity, thereby improving the capacity for genetic improvement. The objective of this study was to evaluate the effect of self-pollination using heated pollen on pollen tube penetration, fruit set, seed and haploid embryo development in cassava genotypes for the production of haploid cassava. Pollen from two cassava genotypes, NASE3 and NASE14, was heated at 40,50 and $60{ }^{\circ} \mathrm{C}$ for $0.5,1.0$ and $2.0 \mathrm{hr}$ each. The heated pollen was used in six rounds of self-pollinations. Pollen tube penetration was monitored by fluorescent microscopy, followed by early embryo rescue and ovule culture. Ploidy and zygosity were assessed using flow cytometry and single-nucleotide polymorphism analysis, respectively. Pollen germinated on the stigma, grew within the style through the nucellar beak, but did not reach the embryo sac, thus achieving no fertilisation in all the 5756 self-pollinated flowers. There was a reduction in pollen germination (in vitro and in vivo), pollen tube penetration and fruit set with increasing temperature. Heat-treated pollen stimulated division of the egg cell and induced development of parthenocarpic fruits. Up to 6 embryoids per ovule were observed and all regenerated plantlets were diploid, with up to $93.0 \%$ increased homozygosity. For the first time, plant regeneration from ovules, pollinated with fresh pollen at 14 days after pollination, was achieved indicating improved speed in plant regeneration. The data generated are important for the development of protocols for cassava DH plant production.
\end{abstract}

Key Words: Double haploids, embryo rescue, Manihot esculenta 
La forte hétérozygotie du manioc (Manihot esculenta Crantz) complique son amélioration génétique par sélection sélective. La technologie d' haploïde double (DH) peut être utilisée pour améliorer l'hétérozygotie de la culture, améliorant ainsi la capacité d'amélioration génétique. L'objectif de cette étude était d'évaluer l'effet de l'auto-pollinisation à l'aide de pollen chauffé sur la pénétration du tube pollinique, la nouaison, le développement des graines et des embryons haploïdes dans les génotypes de manioc pour la production de manioc haploïde. Le pollen de deux génotypes de manioc, NASE3 et NASE14, a été chauffé à 40,50 et $60^{\circ} \mathrm{C}$ pendant $0,5,1,0$ et 2,0 heure (s) chacun. Le pollen chauffé a été utilisé dans six cycles d'auto-pollinisation. La pénétration du tube pollinique a été surveillée par microscopie fluorescente, suivie d'un sauvetage précoce des embryons et d'une culture d'ovules. La ploïdie et la zygosité ont été évaluées à l'aide de la cytométrie en flux et de l'analyse du polymorphisme mononucléotidique, respectivement. Le pollen a germé sur le stigmate, s'est développé dans le style à travers le bec nucellaire, mais n'a pas atteint le sac embryonnaire, n'obtenant ainsi aucune fécondation dans toutes les 5756 fleurs autogames. Il y avait une réduction de la germination du pollen (in vitro et in vivo), de la pénétration du tube pollinique et de la nouaison avec l'augmentation de la température. Le pollen traité thermiquement a stimulé la division de l'ovule et induit le développement de fruits parthénocarpiques. Les 6 embryoïdes par ovule ont été observés et toutes les plantules régénérées étaient diploïdes, avec 93,0\% d'augmentation d'homozygotie. Pour la première fois, la régénération des plantes à partir des ovules, pollinisées avec du pollen frais 14 jours après la pollinisation, a été réalisée, indiquant une vitesse améliorée de régénération des plantes. Les données générées sont importantes pour l'élaboration de protocoles de production de plantes de manioc de $\mathrm{DH}$.

Mots Clés: haploïdes doubles, sauvetage d'embryons, Manihot esculenta

\section{INTRODUCTION}

Cassava (Manihot esculenta Crantz), a woody shrub of family Euphorbiaceae, is the third most important staple food crop sustaining millions of people in developing countries; especially in sub-Saharan Africa (Howeler et al., 2013). Despite the fact that the crop shows relative adaptability and good performance in marginal soils and under drought, cassava production is constrained by numerous diseases and pests, sometimes accounting for up to $100 \%$ of the losses (Obiri et al., 2017). To overcome these challenges, cassava breeding holds the greatest promise because of large natural genetic variability and broad genetic base, which provide opportunities for genetic improvement (Fukuda et al., 2002).

Cassava breeding is hampered by long breeding cycles and its high heterozygosity, that make its improvement slow and inefficient (Wang et al., 2014; Ceballos et al., 2015).
High levels of heterozygosity in cassava are preserved by frequent cross pollination, coupled with centuries of farmer-based vegetative propagation (Wang et al.. 2011). This makes even simple monogenic traits difficult to introgress, due to unpredictable back-crossing results.

This notwithstanding, some progress has been made in breeding towards control of cassava mosaic disease (Hahn et al., 1980), cassava brown streak disease (Patil et al., 2015), enhanced nutritional levels (Stupak, 2008; Nassar and Ortiz, 2010), yield increase (Nassar and Ortiz, 2010), increased dry matter content (Kawano, 2003) and drought resistance (Okogbenin et al., 2013). In such heterozygous species, the breeding schemes can be drastically improved using doubled haploid $(\mathrm{DH})$ plants, which produces large numbers of homozygous lines, after a single round of pollination.

$\mathrm{DH}$ plants are genotypes formed as a result of spontaneous or induced chromosome 
duplication of haploid cells (Germana, 2011a; Kumar and Choudhary, 2020). The main advantage of DH lines is their homozygosity and genetic purity; and therefore, is essential in basic genetics research, molecular biology, and facilitation of plant breeding (Germana, 2011b). DHs are useful in improving the speed and efficiency of the otherwise inefficient and cumbersome classical methods of plant breeding, because heterozygosis is overcome quickly (Chen et al., 2011; Piosik et al., 2016).

There are various techniques used to induce DHs (Murovec and Bohanec, 2012). Such techniques used in different plant species include wide crosses (Wêdzony et al., 2009; Mishra and Goswami, 2014), pollination using a haploid inducer line (Murovec and Bohanec, 2012), pollination using irradiated pollen (Godbole and Murthy, 2012); androgenesis (Forster et al., 2007; Shumilina et al., 2020), and a culture of unfertilised ovules (Mishra and Goswami, 2014). Other techniques include ovule or ovary cultures in which DHs are produced from the female gametophyte via either gynogenesis or parthogenesis. In gynogenesis, unfertilised egg cells are stimulated to divide by plant in vitro pretreatment, giving rise to haploid plants (San and Gelebart, 1986; Bohanec et al., 1995; Michalik et al., 2000; Bohanec et al., 2009). In parthenogenesis, DHs arise from stimulation by pollination with pollen that has been subjected to heat, high energy irradiation, or pollen donated from other plant taxa at a genera or species level (wide pollination) (ForoughiWehr and Wenzel, 1993).

DH induction in cassava was studied previously, in which calli of varied ploidy levels including haploids, were generated but no plants were regenerated (Wang et al., 2011; Perera et al., 2014). An initial step in the production of DHs via gynogenesis in cassava was recently described by Lentini et al. (2020a), involving use of unpollinated ovules from ovaries 1 day post anthesis, for the induction of embryo formation. In our earlier study, while progeny derived from self- pollination with irradiated pollen yielded frequencies of $28-55 \%$ of homozygous loci, none of the regenerated cassava plants was haploid (Buttibwa et al., 2015). Recently, our attempt to use castor bean pollen in wide crosses with cassava, resulted in increased homozygosity and automictic parthenogenesis, but no DH plants were regenerated (Baguma et al., 2019).

Pollination with heat-treated pollen is an alternative to the use of irradiated pollen and wide crosses, and has been used for the induction of haploids in Aspen (Lawson et al., 1968), but not in cassava. Double haploidy using heat-treated pollen involves pollination with heat-treated pollen and use of immature embryo rescue techniques under in vitro conditions. The key determinants in the success of this process are temperature used for the treatment, stage of embryo development, culture media formulation, composition, and growth conditions (Germana, 2011a). Heat-treated pollen can germinate on the stigma, grow through the style, but may not reach the embryo sac to stimulate the development of haploid embryos, but this is not known in cassava.

The objective of this study was to evaluate the effect of heating pollen on pollen tube penetration, fruit set, seed and haploid embryo development in cassava genotypes for the production of haploid cassava.

\section{MATERIALS AND METHODS}

Plant materials. Plants of two elite 'Ugandan' cassava genotypes, namely, NASE3 and NASE14, were grown at the National Crops Resources Research Institute (NaCRRI), Namulonge, Uganda; approx. 100 plants per plot, situated $\sim 500$ metres away from neighbouring cassava fields. National Crops Resources Research Institute, Namulonge is located at $0^{\circ} 321 \mathrm{~N}, 32^{\circ} 371 \mathrm{E}$ at 1150 meters above sea level. Namulonge has an annual mean temperature of $27^{\circ} \mathrm{C}$, relative humidity of $65 \%$, and deep loamy clay soils. The soils are weakly 
acidic, with $\mathrm{pH}$ of 5 to 6 , and organic matter levels of 2 to $3 \%$ in the top soil (Yada et al., 2010). The rainfall shows a bimodal pattern, with a tropical wet and mild dry climate (Yada et al., 2010). NASE3 and NASE14 were selected because they are farmer-preferred, flower profusely and are also highly responsive in tissue culture.

Collection and heat-treatment of pollen. Cassava plants were grown for 6 months in a field at Namulonge in dimensions $50 \mathrm{~m}$ by 50 $\mathrm{m}$. Inflorescence on different plants of NASE3 and NASE14 genotypes with mature female flowers ready for pollination ( $\sim 6$ months after planting), were identified and bagged, 2-3 days prior to pollination to prevent unwanted pollinations (Ramos Abril et al., 2019). On the day of pollination, inflorescences on mature male flower buds (about to dehisce, and containing mature pollen) were identified, collected and placed in plastic Petri dishes. Petri dishes were sealed using parafilm, to avoid hydration of the buds and the pollen; and wrapped in aluminum foil, while ensuring air, light- and water-tight conditions inside the sealed Petri dishes.

Water baths were set up at 50 and $60{ }^{\circ} \mathrm{C}$ for the heating treatment. The male flower buds were then subjected to heat treatment in water baths, by submerging the sealed Petri dishes under water at 40,50 and $60{ }^{\circ} \mathrm{C}$ for $0.5,1.0$ and 2.0 hours. Quantities of $200 \mathrm{~g}$ were placed on top of the Petri dishes to keep them submerged under hot water. Heating of pollen and pollinations were performed on the same day.

Pollination with heat-treated pollen. The heated male flower buds containing pollen were opened and used to self-pollinate mature female flowers in the field (which had been bagged 2-3 days earlier). Pollination was done by brushing the heat-treated pollen from the male flower buds on the stigma manually. Six rounds of self-pollination were carried out. Selfpollination with non-heated (fresh) pollen served as controls. After self-pollination, the inflorescences were re-bagged for at least 3 days to eliminate contamination by unwanted external pollen. Pollen tube penetration capacity into the embryo sac, for each pollination event, and in vitro germination capacity were monitored and quantified.

Field observations were made on the total number of self-pollinations made per temperature treatment. After pollination the experimental set up was categorised into the first and second experiment. In the first experiment, ovules were rescued 14 DAP, after which ovule rescue was done. In the second experiment, the number of surviving fruits (cyathia) per treatment was recorded up to 21 DAP, and embryos were rescued. Data were recorded on seed-set (seeded or seedless embryos), and number of embryos recovered in second experiment. Pollination with fresh pollen (pollen not heat-treated) was used as a control.

In vitro pollen germination tests. Both fresh (non-heated) and heat-treated pollen were germinated on a medium, as described by Brewbaker and Kwack (1963), with modifications. These modifications included addition of $0.03 \%$ casein hydrolysate, $12.5 \%$ w/v poly ethylene glycol-600 (PEG-600), and $15 \mathrm{Mm} \mathrm{N}$-morpholino ethanesulfonic acid (MES) into the medium. The $\mathrm{pH}$ of the medium was adjusted to $\mathrm{pH} 5.8$ and autoclaved for 30 min at $120^{\circ} \mathrm{C}$. The medium contained $100 \mathrm{mg}$ $\mathrm{L}^{-1}$ boric acid; $300 \mathrm{mg} \mathrm{L}^{-1}$ calcium nitrate; 200 $\mathrm{mg} \mathrm{L}^{-1}$ magnesium sulphate; $100 \mathrm{mg} \mathrm{L}^{-1}$ potassium nitrate; and 5\% sucrose.

Following incubation in a dark humid chamber at $40{ }^{\circ} \mathrm{C}$ and $100 \%$ relative humidity for 24 hours, the pollen was examined under an inverted microscope (Nikon Alphaphot-2 YS2, Japan) as described by Kundu et al. (2014). Observations on pollen germinations were done on five replicates of 100 pollen grains per treatment. Pollen germination on the medium was used as an indicator for pollen viability, in which a pollen grain was scored 
as germinated if a pollen tube was observed. Pollen germination frequencies were determined and comparisons made between germinated and non-germinated pollen grains, and between heat-treated and fresh pollen.

In vivo pollen germination analysis. To collect the sample tissues for in vivo pollen germination analysis, 2 to 3 female flowers of NASE3 and NASE14, pollinated with fresh or heat-treated pollen (at 40,50 and $60{ }^{\circ} \mathrm{C}$ for $0.5,1.0$ and $2.0 \mathrm{hr}$ ) were detached from the plants at 1,2 and 3 DAP. Bracts were removed and female flowers (pistils) submerged immediately in the fixation solution in falcon tubes. The fixation solution was prepared one day in advance; and contained ethanol and acetic acid at a 3:1 v/v ratio. The volume of the fixative was 5 times higher than that of the fixated tissue to avoid dilution of the fixative by the water diffusing from the fresh tissues. Samples were carried from the field to the laboratory in the next 20 to 30 minutes, and stored in a refrigerator at $4{ }^{\circ} \mathrm{C}$ in the same fixing solution. The fixing solution was renewed every 24-hr intervals until further processing. For extended preservations, samples were stored in $70 \%$ ethanol.

Fixation and microscopic observations. To prepare samples for fixation and subsequent observations under the microscope, the old fixative solution was decanted off and $8 \mathrm{M}$ $\mathrm{NaOH}$ added to macerate pistils for $4 \mathrm{hr}$ in darkness at room temperature $\left(25^{\circ} \mathrm{C}\right)$. This was followed by three washes, each of 5 minutes with $0.5 \mathrm{~N} \mathrm{~K}_{2} \mathrm{HPO}_{4}$ at $\mathrm{pH} 10-12$, to neutralise $\mathrm{NaOH}$. Pistils were then washed thrice with $500 \mathrm{ml}$ of $0.1 \%$ aniline blue in $0.5 \mathrm{~N} \mathrm{~K}_{2} \mathrm{HPO}_{4}$ at $\mathrm{pH} 10-12$, and stained in the same solution for $1 \mathrm{hr}$ at $4{ }^{\circ} \mathrm{C}$ in darkness, as described by Ramos Abril et al. (2019). The pistils were removed from the stain and placed in a drop of glycerol on a glass slide. Stigmas were separated by cutting and the ovaries dissected to extract ovules. The ovary wall tissues were discarded and a drop of $0.1 \%$ aniline blue solution added on the ovules and stigmas, covered with a cover slip and then gently squashed. Observations of pollen germination and pollen tube growth were made with a fluorescence microscope; and images taken using a camera head (Nikon DS-L3). Pistils pollinated with fresh pollen were used as control.

Embryo rescue and ovule culture. At 14 and 21 days after pollination (DAP), cyathia (fruits) from the first and second experiment, respectively, were harvested and placed in ziplock bags containing a refrigerant gel; and transported from the field to the laboratory. Cyathia (fruits) were surface sterilised by soaking in $70 \%$ ethanol for one minute, in $1.5 \%$ sodium hypochlorite $(\mathrm{NaClO})$, with 3 drops of Tween 20 for 20 minutes. This was followed by four washes of each 5 minutes with sterile distilled water, in a laminar flow hood. Ovaries were then cut longitudinally into three sections. Individual carpels of the ovary, containing one ovule each per locus, were isolated and cultured. The isolated carpels were placed with the basal cut end on MS3 medium (Lentini et al., 2020b). Thirty ovary-slices were placed per Petri dish of $90 \mathrm{~cm}$ x $15 \mathrm{~cm}$ diameter and sealed with a cling film. After 4 weeks of culture, ovules were dissected and isolated from each carpel, and cultured with the adaxial side facing the MS3 medium. Cultures were then kept in the dark $12 \mathrm{hr}$-day and $12 \mathrm{hr}$-night photoperiod at $28-30{ }^{\circ} \mathrm{C}$ for 4 weeks; and then transferred to new MS3 medium.

\section{Culture medium for induction of embryos} from ovules. At 7 DAP, ovules from selfpollinated flowers with heat-treated or fresh pollen were cultured on MS3 medium as described by Lentini et al. (2020b). The medium contained MS macro- and micronutrients, supplemented with $0.8 \mathrm{mg} \mathrm{L}^{-1} \mathrm{CuSO}_{4}$ $5 \mathrm{H}_{2} \mathrm{O}, 2.5 \mathrm{mg} \mathrm{L}^{-1}$ nicotinic acid, $1.2 \mathrm{mg} \mathrm{L}^{-1}$ pyridoxine- $\mathrm{HCl}, 10 \mathrm{mg} \mathrm{L}^{-1}$ thiamine- $\mathrm{HCl}, 4 \mathrm{mg}$ $\mathrm{L}^{-1}$ glycine, and $500 \mathrm{mg} \mathrm{L}^{-1}$ myo-inositol. Also 
added was $0.2 \mathrm{mg} \mathrm{L}^{-1}$ biotin, $0.2 \mathrm{mg} \mathrm{L}^{-1} \mathrm{Ca}-$ panthotenate, $0.2 \mathrm{mg} \mathrm{L}^{-1}$ ascorbic acid, $0.4 \mathrm{mg}$ $\mathrm{L}^{-1}$ riboflavin, $200 \mathrm{mg} \mathrm{L}^{-1} \mathrm{~L}$-proline, $2 \mathrm{mg} \mathrm{L}^{-1}$ 2,4-D, $2 \mathrm{mg} \mathrm{L}^{-1} \mathrm{BAP}, 1 \mathrm{mg} \mathrm{L}^{-1}$ gibberellic acid (GA3), and $8 \%$ sucrose; and all solidified with $0.3 \%$ phytagel (Lentini et al., 2020b).

The $\mathrm{pH}$ of the medium was adjusted to 5.8 using $0.5 \mathrm{~N} \mathrm{HCl}$, before autoclaving at $121^{\circ} \mathrm{C}$ for 15 minutes. Ovules were cultured on this media for embryo formation. At the end of the 4-week of culture, the ovules were extracted from the carpels. The extracted ovules were transferred onto fresh MS3 medium under the same growth conditions at $28{ }^{\circ} \mathrm{C}$ under a $12 /$ $12 \mathrm{hr}$-light versus $12 / 12$ dark period for 84 days. Data were collected by recording the number of ovules bulging and callus formed from ovules.

Fruits harvested at 21 DAP were dissected under a microscope and the embryos extracted. The embryos were cultured in vitro on modified MS basal medium (Murashige and Skoog, 1962) on deep petri dishes/glass jars with radicles pushed down into the medium. The M6 medium has half MS basal salts, supplemented with $1.0 \mathrm{mg} \mathrm{L}-1$ gibberellic acid (GA3), $2 \%$ sucrose and $0.2 \%$ gelrite or agar as described by Yan et al. (2014). The embryos at 21 DAP were incubated at $28 \pm 1$ ${ }^{\circ} \mathrm{C}$ under a $12 / 12 \mathrm{hr}$ light/dark period with light supplied by white fluorescent tubes $(25 \mu \mathrm{mol}$ $\mathrm{m}^{-2} \mathrm{~s}^{-1}$ ) in a growth room for four weeks.

Embryo maturation and conversion into plantlets from ovules at 14 DAP. Primary embryos were sub-cultured on maturation medium consisting of MS salts and organics supplemented with $0.8 \mathrm{mg} \mathrm{L}^{-1} \mathrm{CuSO}_{4} 5 \mathrm{H}_{2} \mathrm{O}, 1$ $\mathrm{mg} \mathrm{L}^{-1}$ NAA and $2 \%$ sucrose; and solidified with $0.7 \%$ agar. Cultures were incubated at $28^{\circ} \mathrm{C}$ in $12 / 12 \mathrm{hr}$ light/dark period for 15 days, or until the cotyledons developed and turned green (Stamp and Henshaw, 1987). After 15 days of culture on a maturation medium, individual embryos or clusters of embryos with cotyledons were transferred onto MS salts, supplemented with $0.8 \mathrm{mg} \mathrm{L}^{-1} \mathrm{CuSO}_{4} \cdot 5 \mathrm{H}_{2} \mathrm{O}$,
$0.45 \mathrm{mg} \mathrm{L}^{-1} \mathrm{BAP}$ and 12/12 hr light/dark period, for further development. The remaining early stage embryos were re-cultured on fresh maturation medium. After cotyledons expanded and roots formed, plantlets were transferred onto the medium for plant elongation for full development. This elongation medium (4E) consisted of MS salts and organics supplemented with $0.8 \mathrm{mg} \mathrm{L}^{-1} \mathrm{CuSO}_{4}, 20 \%$ sucrose solidified with $0.45 \%$ agar cultured at $28{ }^{\circ} \mathrm{C}$ in $12 \mathrm{hr}$ photoperiod.

Histology analysis on the rescued embryos. To determine how heat-treatment of pollen may affect embryo development, cell divisions and differentiation in the embryo sac region, histological analyses were done on a few ovules to track embryo developmental changes following pollination. The ovules were excised from fruits at $21 \mathrm{DAP}$, and then fixed in glacial acetic acid to $96 \%$ ethanol solution in a 1:3 (v/ v) ratio, and kept in darkness at $4{ }^{\circ} \mathrm{C}$ for at least 3 hours. The ovules were prepared using a tissue processor (Leica TP 1020), embedded in Paraffin wax (Histowax), and then sectioned using a rotary microtome (Leica RM 2235; section thickness, $5 \mu \mathrm{M}$ ). They were stained with Schiff's reagent and counterstained with Naphthol Blueblack, NBB $(5 \% \mathrm{w} / \mathrm{v})$. Stained sections were mounted using Depex mounting medium to make permanent slides. Examination of slides was performed under an inverted light microscope and images taken using a camera head (Nikon DS-L3).

\section{Determination of ploidy and zygosity} analysis. Flow cytometry was used to determine the ploidy levels of regenerants, using young leaves from in vitro cultured plants. Plant tissue (approx 0.5-1.0 $\mathrm{cm}^{2}$ size) was cut with a razor blade in $1 \mathrm{ml}$ of lysis buffer [10 mM Tris, $2 \mathrm{mM} \mathrm{MgCl} 26 \mathrm{H}_{2} \mathrm{O}, 50$ $\mathrm{mM}$ sodium chloride, $1 \% \quad(\mathrm{v} / \mathrm{w})$ polyvinylpyrolidone, $0.1 \%(\mathrm{v} / \mathrm{v})$ Triton $\mathrm{X}-100$, $\mathrm{pH} 7.0$ with addition of $1 \mathrm{mg}$ of 4'6-diamidino2-phenylindoole (DAPI) (Ochatt et al., 2011). 
The suspension was filtered through a 30$\mathrm{mm}$ nylon filter and stained at room temperature for 5 minutes. The suspensions were measured for relative nuclear DNA content, using Partec CA II (Partec, Münster, Germany). Leaves of diploid $(2 \mathrm{n}=2 \mathrm{x}=18)$ mother plants of cassava (NASE3 and NASE14) were used as a reference standard; while diploid Medicago sativa was used as an external standard. Ploidy was determined by comparing a position of the peak of the diploid standard, placed on channel 100, with the position of the peak corresponding to G1 nuclei of the regenerants.

To determine the homozygosity of the samples, genotyping was performed using single nucleotide polymorphisms (SNPs). DNA was extracted from regenerated plantlets using a Qiagen ${ }^{\circledR}$ kit, following the manufacturer's instructions. The quantity of DNA was estimated by comparing the fluorescent yield of the samples with a series of lambda ( $(\ddot{e})$ DNA standards at varying known concentrations. The quality was checked through the digestion of $250 \mathrm{ng}$ of the genomic DNA from 10 random samples, with the restriction enzyme EcoRI at $65{ }^{\circ} \mathrm{C}$ for two hours; and thereafter visualised on agarose gel.

DNA samples were genotyped at the Biosciences for Eastern and Central Africa (BecA) hub in Nairobi, Kenya. Genotyping by sequencing (GBS) was done using a protocol described by Elshire et al. (2011), wherein the DNA was digested by the enzyme ApeKI, a type II restriction endonuclease that recognises a 5-base degenerate sequence GCWGC, in lengths of $100 \mathrm{bp}$, as recommended by Hamblin and Rabbi (2014). The binding between ApeKI cleavage fragments and the adapter was performed after the digestion of samples and a 192-plex sequencing run.

In order to analyse the sequences and quality filters, the TASSEL software package, version 5.2.37 (Bradbury et al., 2007) was used. A total of 22,618 heterozygous and polymorphic SNPs were used to assay the
DNA samples. The DNA of heterozygous mother plants, NASE3 and NASE14, was used as a control. We limited our comparisons by focusing on heterozygous alleles between mother samples and their respective progeny calluses.

Data analysis. Mean numbers of flowers, fruits, ovules, seeds, embryos, for each pollination event were computed. From these, mean numbers of flowers, fruits, ovules, seeds, for each pollination event were computed for six rounds of pollination. For in vitro pollen germination, mean numbers and percentages of germinated pollen grains were also computed for six rounds of pollen germination tests using R-statistics (Verzani, 2018). The results were computed using the Shapiro-Wilk normality test (Villasenor and Estrada, 2009) and by looking at the normality of the quantile-quantile plots (Q-Q plot). Following the normality test, the Kendall rank correlation coefficient (Abdi, 2007) was computed to examine the relationships between changes in heat-treated pollen and the corresponding effect on pollen viability, fruit set and regeneration. Analysis of variance (ANOVA) was used to determine the significant differences between in the treatments.

\section{RESULTS}

\section{In vitro and in vivo viability and germination}

of pollen. Pollen germination was evident across all heat treatments in the two genotypes studied (Table 1; Fig. 1). There were higher germination percentages for fresh pollen than in the heat-treated cases. Generally, pollen germination rates decreased with increased temperatures, with evidence of a negative correlation $(r=-0.72)$. For example, pollen heated at 50 to $60{ }^{\circ} \mathrm{C}$ registered germination percentages of 0.0 and $0.0-2.3 \%$ for NASE3 and NASE14, respectively (Table 1). Fresh (non-heated) pollen grains exhibited varying germination percentages and pollen tube growth (Fig. 1, Table 1). NASE14 fresh pollen 
TABLE 1. Pollen treatment, in vitro pollen germination, pollinations and the results of Fruit Formation (FF), ovule Formation (OF) and calli (CF) in cassava genotypes NASE3 and NASE14. Plants pollinated with heat-treated pollen at $40{ }^{\circ} \mathrm{C}$ were not considered under experiment 2

\begin{tabular}{|c|c|c|c|c|c|c|c|c|c|c|c|c|}
\hline \multirow[t]{2}{*}{ Genotype } & \multicolumn{7}{|c|}{ Experiment 1} & \multicolumn{5}{|c|}{ Experiment 2} \\
\hline & $\begin{array}{l}\text { Heat- } \\
\text { treatment } \\
\text { of pollen }\end{array}$ & $\begin{array}{l}\text { Flowers } \\
\text { pollinated }\end{array}$ & $\begin{array}{l}\text { Mean } \\
\text { fruit } \\
\text { formation }\end{array}$ & $\begin{array}{l}\text { Mean } \\
\text { ovule } \\
\text { formation }\end{array}$ & $\begin{array}{l}\text { Mean } \\
\text { callus } \\
\text { formation }\end{array}$ & $\begin{array}{l}\text { Germination } \\
\text { rate }(\%)\end{array}$ & $\begin{array}{l}\text { SD of } \\
\text { Germination }\end{array}$ & $\begin{array}{l}\text { Total } \\
\text { fruit } \\
\text { set }\end{array}$ & $\begin{array}{l}\text { Mean } \\
\text { fruit } \\
\text { set }\end{array}$ & $\begin{array}{l}\mathrm{SD} \text { of } \\
\text { fruit set }\end{array}$ & $\begin{array}{l}\text { Total } \\
\text { ovules }\end{array}$ & $\begin{array}{l}\text { Number } \\
\text { of embryos }\end{array}$ \\
\hline \multirow[t]{11}{*}{ NASE3 } & $40^{\circ} \mathrm{C} \_0.5 \mathrm{hr}$ & 189 & 55.5 & 16 & 12.8 & 7.6 & 2.1 & & & & & \\
\hline & $40^{\circ} \mathrm{C} \_1.0 \mathrm{hr}$ & 213 & 33.7 & 19.2 & 8 & 4 & 1 & & & & & \\
\hline & $40^{\circ} \mathrm{C} \_2.0 \mathrm{hr}$ & 176 & 39.6 & 13.7 & 8.5 & 26.7 & 5.8 & & & & & \\
\hline & $50^{\circ} \mathrm{C} \_0.5 \mathrm{hr}$ & 289 & 38.6 & 66.6 & 41.2 & 0 & 0 & 8 & 3.2 & 1 & 14 & 2 \\
\hline & $50^{\circ} \mathrm{C}_{-} 1.0 \mathrm{hr}$ & 270 & 37.9 & 37.7 & 16.2 & 0 & 0 & 0 & 0 & 0 & 0 & 0 \\
\hline & $50^{\circ} \mathrm{C} \_2.0 \mathrm{hr}$ & 483 & 58.8 & 33.6 & 7 & 0.2 & 0.3 & 4 & 0.5 & 0.7 & 5 & 2 \\
\hline & $60^{\circ} \mathrm{C} \_0.5 \mathrm{hr}$ & 284 & 27.8 & 73.3 & 26.2 & 0 & 0 & 11 & 2.7 & 3.8 & 20 & 8 \\
\hline & $60^{\circ} \mathrm{C} \_1.0 \mathrm{hr}$ & 355 & 49.7 & 56.4 & 13.8 & 0 & 0 & 14 & 5.7 & 4.5 & 20 & 12 \\
\hline & $60^{\circ} \mathrm{C} \_2.0 \mathrm{hr}$ & 401 & 15.8 & 50.3 & 3 & 0 & 0 & 8 & 1.2 & 1.7 & 10 & 3 \\
\hline & Fresh Pollen & 338 & 59.6 & 59.5 & 37.5 & 60 & 10 & 95 & 34.7 & 42 & 203 & 19 \\
\hline & & 2998 & $\mu=40.4$ & \multicolumn{2}{|c|}{$\mu=42.6 \mu=17.4$} & & & & & & & \\
\hline \multirow[t]{11}{*}{ NASE14 } & $40^{\circ} \mathrm{C} \_0.5 \mathrm{hr}$ & 226 & 8.4 & 84.7 & 35 & 12.4 & 8.2 & & & & & \\
\hline & $40^{\circ} \mathrm{C} \_1.0 \mathrm{hr}$ & 226 & 27.4 & 46.8 & 10 & 3.6 & 3.8 & & & & & \\
\hline & $40^{\circ} \mathrm{C} \_2.0 \mathrm{hr}$ & 345 & 21 & 79.8 & 1.8 & 62.9 & 5.8 & & & & & \\
\hline & $50^{\circ} \mathrm{C} \_0.5 \mathrm{hr}$ & 275 & 3.4 & 68.8 & 35 & 0.7 & 1.2 & 2 & 4.4 & 6.2 & 4 & 2 \\
\hline & $50^{\circ} \mathrm{C}_{-} 1.0 \mathrm{hr}$ & 229 & 14.7 & 37.2 & 7.5 & 0.1 & 0.2 & 4 & 8 & 11.3 & 0 & 0 \\
\hline & $50^{\circ} \mathrm{C} \_2.0 \mathrm{hr}$ & 345 & 12.3 & 49.5 & 2 & 1.3 & 2.3 & 1 & 1.2 & 1.7 & 1 & 0 \\
\hline & $60^{\circ} \mathrm{C} \_0.5 \mathrm{hr}$ & 259 & 4 & 71.9 & 35 & 0 & 0 & 5 & 1.1 & 1.5 & 10 & 3 \\
\hline & $60^{\circ} \mathrm{C}_{-} 1.0 \mathrm{hr}$ & 312 & 17.1 & 55.1 & 9.5 & 0 & 0 & 2 & 0.4 & 0.5 & 5 & 1 \\
\hline & $60^{\circ} \mathrm{C} \_2.0 \mathrm{hr}$ & 355 & 23.1 & 60.4 & 3.5 & 0 & 0 & 4 & 0.7 & 1 & 8 & 2 \\
\hline & Fresh Pollen & 186 & 27.6 & 95 & 51.2 & 72.8 & 11.8 & 24 & 26 & 23.9 & 65 & 40 \\
\hline & & 2758 & $\mu=15.9$ & \multicolumn{2}{|c|}{$\mu=64.9 \mu=19.1$} & & & & & & & \\
\hline
\end{tabular}




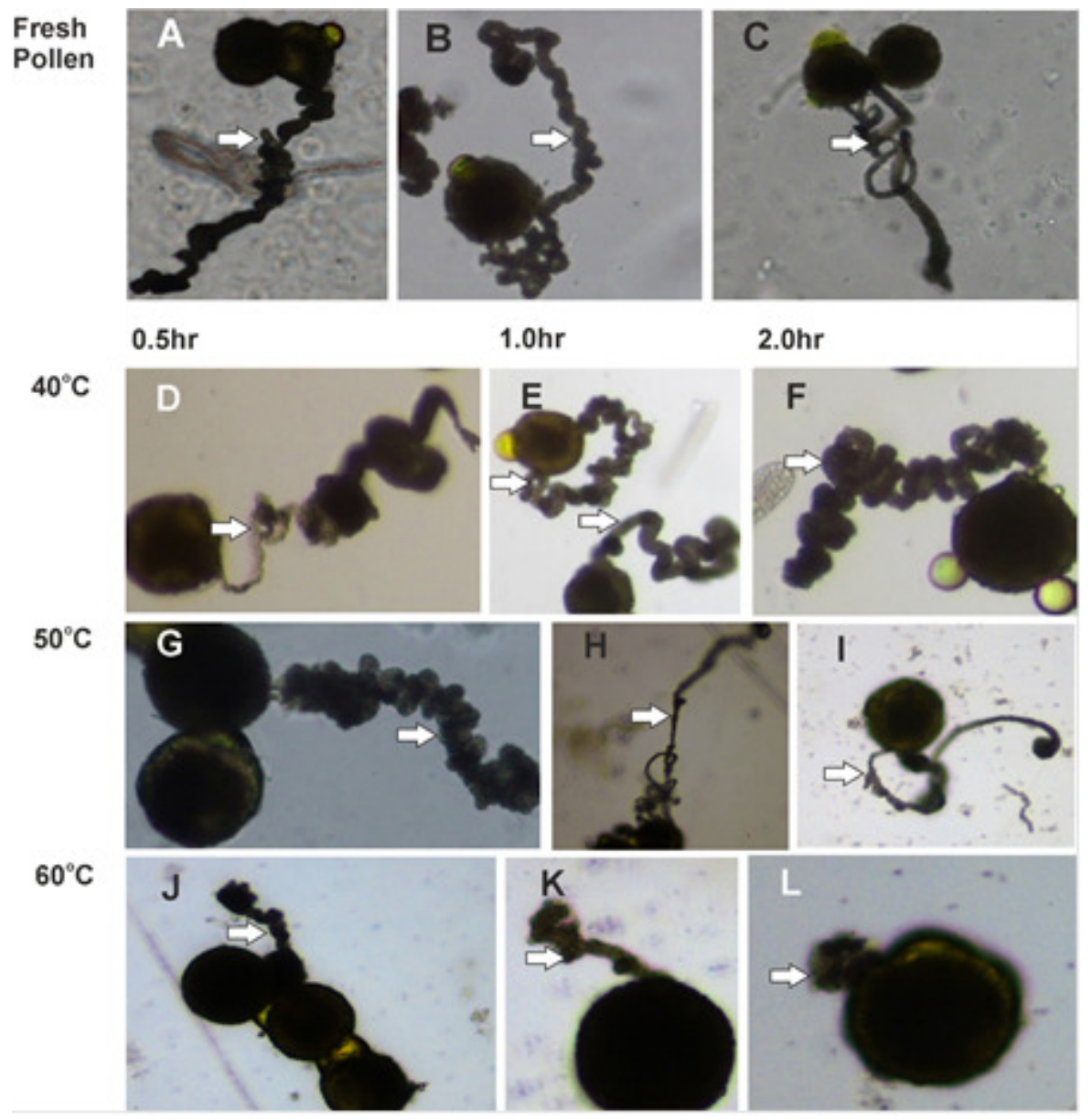

Figure 1. In vitro germination of pollen derived from cassava genotype NASE3. Germination of fresh pollen (A, B and C) in comparison germination of pollen treated with temperatures of $40^{\circ} \mathrm{C}, 50^{\circ} \mathrm{C}$ and $60^{\circ} \mathrm{C}$ for different durations of $0.5,1.0$ and $2.0 \mathrm{hrs}$ ( $\mathrm{D}$ to L). In all cases, the thread-like structures are the pollen tubes (white arrows) arising from the germinated pollen. Pollen germination and pollen tube development at $60^{\circ} \mathrm{C}(\mathrm{J}, \mathrm{K}$, and $\mathrm{L})$ was poor. Observations on pollen from cassava genotype NASE14 (data not presented) were similar to those of NASE3.

had the highest germination percentage (72.8\%) compared to NASE3 (60.0\%). A significant difference was observed in pollen germination rates of the test genotypes $(\mathrm{P}<0.05)$ (Table 1$)$, with NASE3 responding more to the heat treatment compared to NASE14.

In vivo pollen germination was observed in fresh and heat-treated pollen in NASE3 (Fig. 2) and NASE14 (Fig. 3). Indeed, pollen heated at $60{ }^{\circ} \mathrm{C}$ for $2.0 \mathrm{hr}$ allowed for the pollen tube growth to the embryo sac, without fertilisation at 3 DAP. In contrast, pollen tubes from fresh pollen grew to reach the embryo sac region within $24 \mathrm{hr}$ after pollination (Fig. 2, Fig. 3). Pollen tubes from heat-treated pollen $\left(60{ }^{\circ} \mathrm{C}\right.$ for $0.5 \mathrm{hr}$ ) germinated on the stigma and formed pollen tubes, which penetrated through the cassava pistil, up to the nucellar beak (Fig. 2D1, Fig. 3D1). Histological examinations on ovules following self-pollinations with heattreated pollen, showed degeneration of the embryo sac 14 DAP (Fig. 2E2-E4). This was evidenced by the presence of many empty 

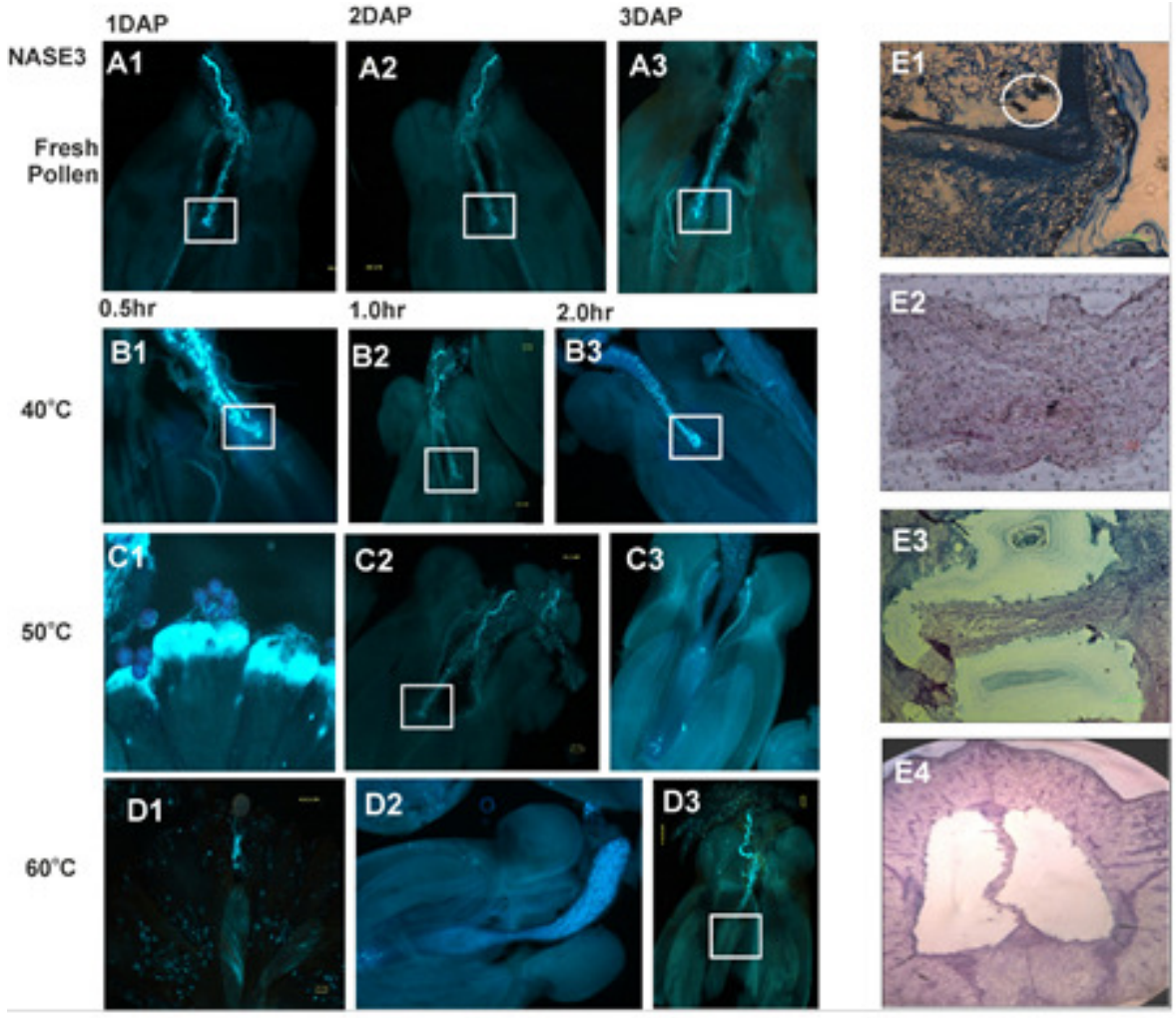

Figure 2. In vivo pollen germination on the stigma and pollen tube penetration at 1,2 and 3 DAP along the style of cassava genotype, NASE3. Pollen tube from fresh pollen entered the embryo sac region (white squares in A1-A3) by 1DAP. Pollen tube penetration at 1, 2, and 3 DAP after pollination with heat-treated pollen at different temperatures $\left(40,50\right.$ and $\left.60{ }^{\circ} \mathrm{C}\right)$ for different periods $(0.5,1.0$ and 2.0 hrs) are shown in B1 to D3. Pollen tube arising from different heat-treated pollen penetrated into the embryo sac region (white squares in B1-B3, and C2). In C1, C3, D1 and D2 the pollen germinated on the stigma but there was no formation of pollen tube, while in D3 the pollen tube could not penetrate the embryo sac region (white square). E1-E4 show NASE3 embryo development 14 DAP with fresh pollen (white circle in E1), whle E2-E4 shows cell ploriferation in the embryo sac region on $21 \mathrm{DAP}$ with $60^{\circ} \mathrm{C}$ for $0.5 \mathrm{hr}$-treated pollen (E2), and degeneration of embryo sac region on pollination with $60{ }^{\circ} \mathrm{C} / 2.0 \mathrm{hr}$ heat-treated pollen $(\mathrm{E} 3, \mathrm{E} 4)$.

embryo sacs with disorganised tissues (Fig. 2E3).

Seed/fruit set and embryo development. A total of 2,998 of NASE3 and 2,758 of NASE14 female flowers in both cases were selfpollinated (Table 1). In NASE3, the highest fruit retention capacity of $58.8 \%$ was observed at $50{ }^{\circ} \mathrm{C}$ for $2.0 \mathrm{hr}$, compared to $28.1 \%$ as highest in NASE14 observed at $60^{\circ} \mathrm{C}$ for 2.0 hr (Fig. 4A). In both NASE3 and NASE14, fruit set was highest when fresh pollen was used in pollination, compared to the $93-100 \%$ reduction in fruit set as result of heat-treated pollen (Table 1).

Dissection and examination of approximately 500 ovules showed that the number of ovules per fruit was 42.6 for NASE3 and 64.9 for NASE14 (Table 1). Inoculation of immature ovules onto MS3 culture medium resulted into the formation of calli from several ovules, three months after initiation on culture (Fig. 5). Multiple embryos emerging from single ovules pollinated with 


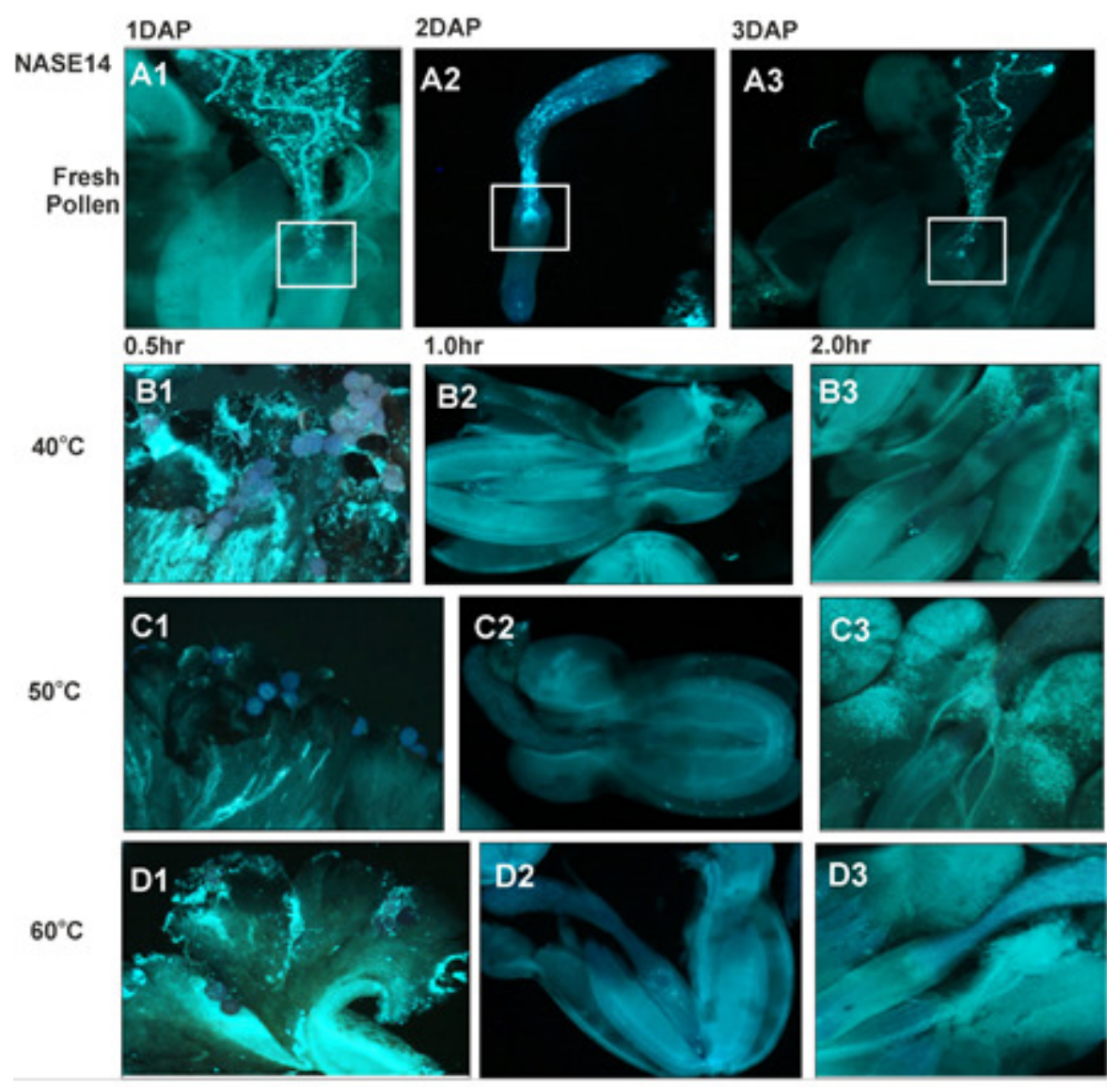

Figure 3. In vivo pollen germination on the stigma and pollen tube penetration at 1,2 and 3 DAP along the style of cassava genotype, NASE14. Pollen tube from fresh pollen entered the embryo sac region (white squares in A1-A3) by 1DAP. A1 is a massive pollen tube in the nucellar beak penetrating into the embryo sac region. Pollen germination at 1,2, and 3 DAP after pollination with heat-treated pollen at different temperatures $\left(40^{\circ} \mathrm{C}, 50^{\circ} \mathrm{C}, 60^{\circ} \mathrm{C}\right)$ for different periods $(0.5,1.0$ and $2.0 \mathrm{hrs})$ are shown in $\mathrm{B} 1$ to D3. Pollen heated for different periods at different temperatures were able to germinate on the stigma surface without formation of pollen tube into the embryo sac region (B1-B3, C1-C3, and D1-D3).

fresh pollen at 14 DAP, were observed (Fig. 5A, 5B and 5C). Ovules obtained from fruits picked at 14 DAP increased in size and later formed callus in both genotypes. Generally, ovule formation (OF) and callus formation (CF) decreased as the temperature and time duration increased. The highest $\mathrm{OF}$ and $\mathrm{CF}$ were recorded from pollinations made using in fresh pollen of NASE14 at 95.0 and $51.2 \%$, respectively (Table 1). In both NASE3 and NASE14, callus formed from the ovules were mucilaginous, transparent and friable; but in some cases it appeared like a compact mass of cells (Fig. 5E). For ovules subjected to heated pollen of $50{ }^{\circ} \mathrm{C}$ for $1.0 \mathrm{hr}$, callus was observed coming from the inside of the ovules (Fig. 5H). Some of the callus formed green spots (Fig. 5K), and rooting was also observed (Fig. 5L).

Plant regeneration and characterisation. Regeneration capacity generally varied across the genotypes (Fig. 4B). Only the embryos obtained from ovules at 21 DAP heat-treated and 14 DAP non-treated; and cultured in vitro developed into individual plants after 3-4 

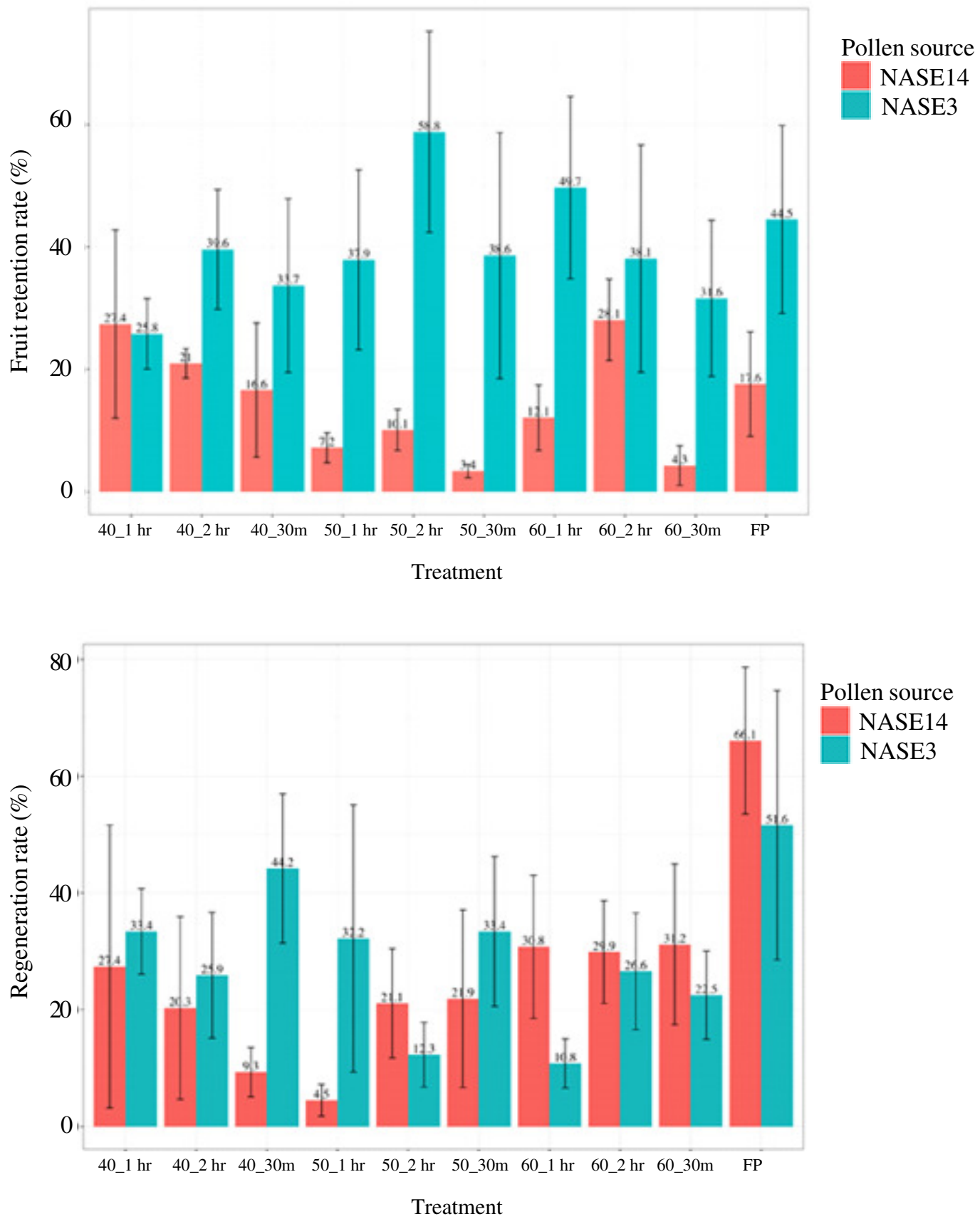

Figure 4. Fruit retention capacity (A) and plant regeneration rate (\%) (B) of genotype NASE3 and NASE14. There was considerable variation in fruit set as evident across genotypes and treatments (A), although increase in temperature resulted in higher fruit abortion. Highest plant regeneration was observed when Fresh pollen was used with evidence of drastic reduction in regeneration at different temperatures (B). 


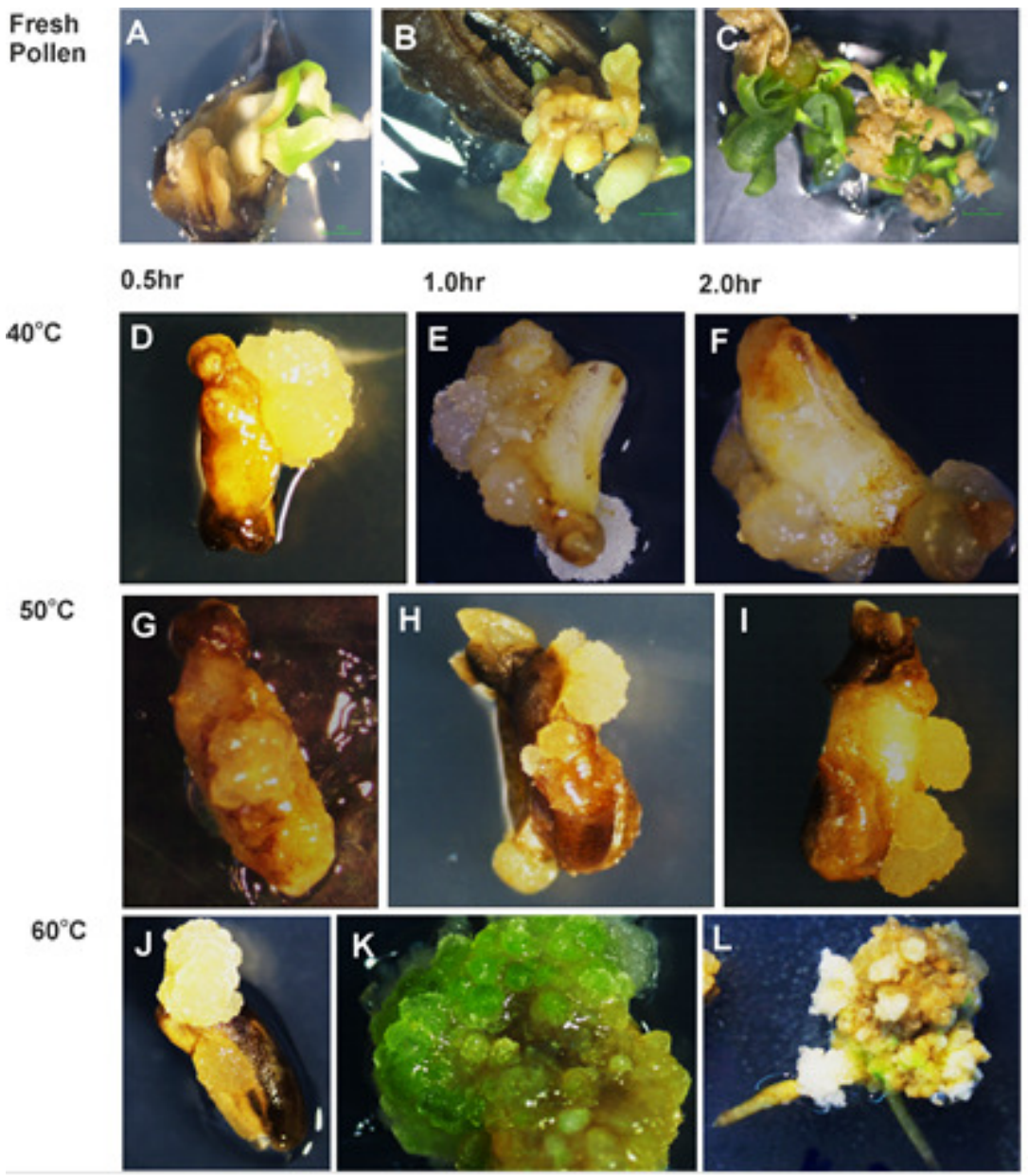

Figure 5. Callus regeneration and direct embryo formation following early ovule culture 14 days after pollination (DAP) for cassava genotype NASE3. A-C: Direct embryo formation from ovules formed from self-pollinations with fresh pollen; (A) embryo formation on culture from ovule pollinated with fresh pollen (B), polyembryos emerging from an ovule following pollinated with fresh pollen, and (C) regeneration of embryos. $\mathrm{D}$ to $\mathrm{L}$ shows calli regeneration from ovules following self-pollination with pollen treated with heat $\left(40,50\right.$ and $\left.60{ }^{\circ} \mathrm{C}\right)$ for different durations of $0.5,1.0$ and $2.0 \mathrm{hr}$. Compared to other calli, those generated from ovules pollinated with $60{ }^{\circ} \mathrm{C}$-treated pollen $(\mathrm{J}, \mathrm{K}$ and $\mathrm{L}$ ) show compact green calli on regeneration and formation of roots form calli transferred on rooting medium. These observations were the same for cassava genotype NASE14.

transfers onto fresh medium (Fig. 6I). Different embryo types were formed from fruits pollinated with heat-treated pollen at 60 ${ }^{\circ} \mathrm{C}$ for different periods. Up to 40 embryos were obtained using fresh pollen in NASE14, and this was higher than the 19 embryos in NASE3 (Table 1). Although there was no significant difference $(\mathrm{P}>0.05)$ in regeneration between the two test genotypes, recovery frequency of the embryos for the treatments was generally higher in NASE3 at $60{ }^{\circ} \mathrm{C}$ for $1.0 \mathrm{hr}$ duration than at $50{ }^{\circ} \mathrm{C}$ for $1.0 \mathrm{hr}$ (Table 1, Fig. 4B). Regeneration of plants (Fig. 6) was not dependent on heat treatment imposed on the pollen $(r=0.047, \mathrm{P}>0.05)$. The majority of plants obtained were diploids (Table 2). 


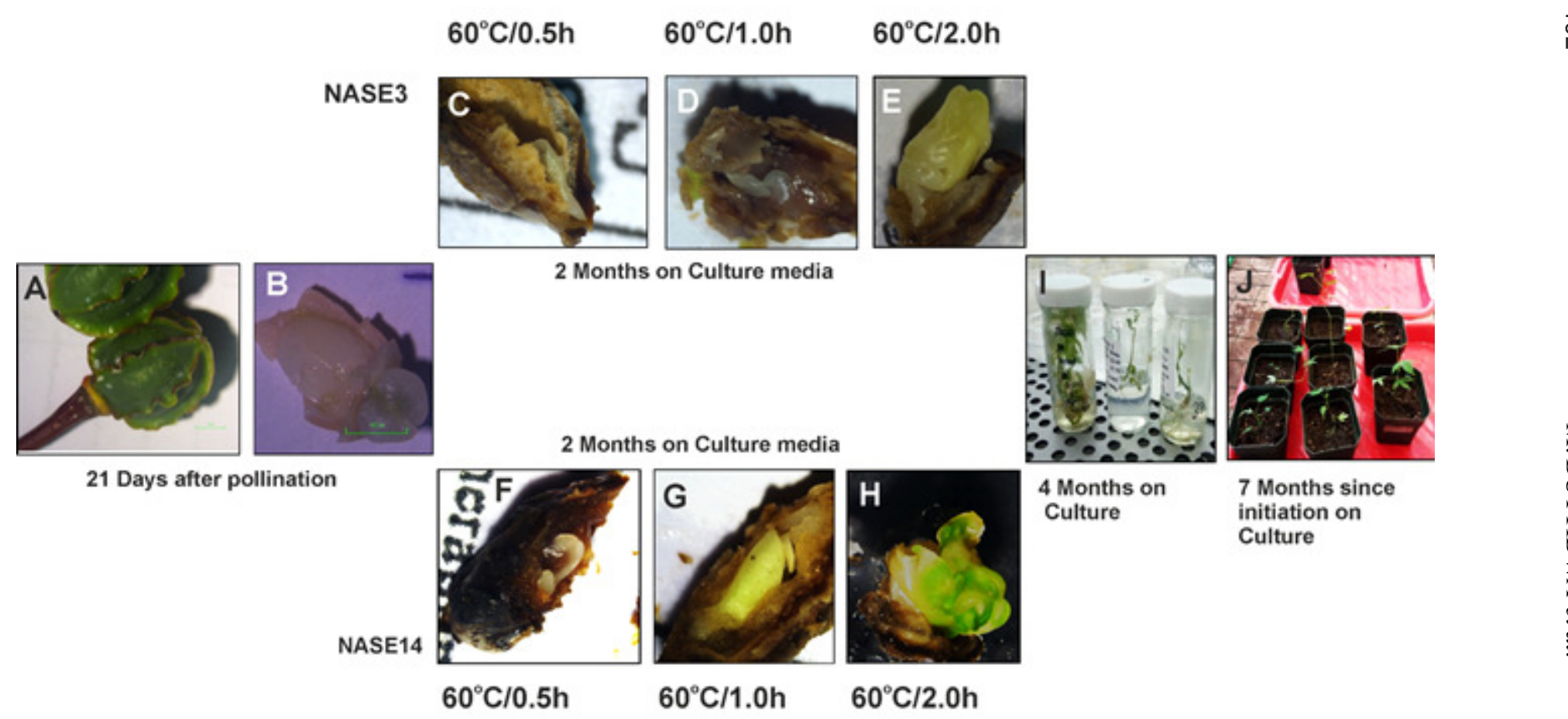

Figure 6. Embryo formation from rescued ovules. Fruits (A) of cassava genotypes NASE3 and NASE14 were picked 21 DAP; their ovules (B) excised out and inoculated on the culture medium. NASE3 ( $\mathrm{C}$ to E) and NASE14 ( $\mathrm{F}$ to H) embryos formed from self-pollinations with pollen heated at $60^{\circ} \mathrm{C}$ for various durations. C and D: the ovules have no endosperm, E: embryos later regenerated into plants. F: ovule has no endosperm compared to $\mathrm{G}$ and $\mathrm{H}$. I and J: Regenerated plants of NASE $360^{\circ} \mathrm{C} / 1.0 \mathrm{hr}$ arising from D on MS medium and weaned in the screen house 7 months after initiation on ovule culture. No plant was regenerated from NASE14 or ovules arising from self-pollinations with other heat-treated pollen. 
Self-pollination with heat-treated pollen in cassava

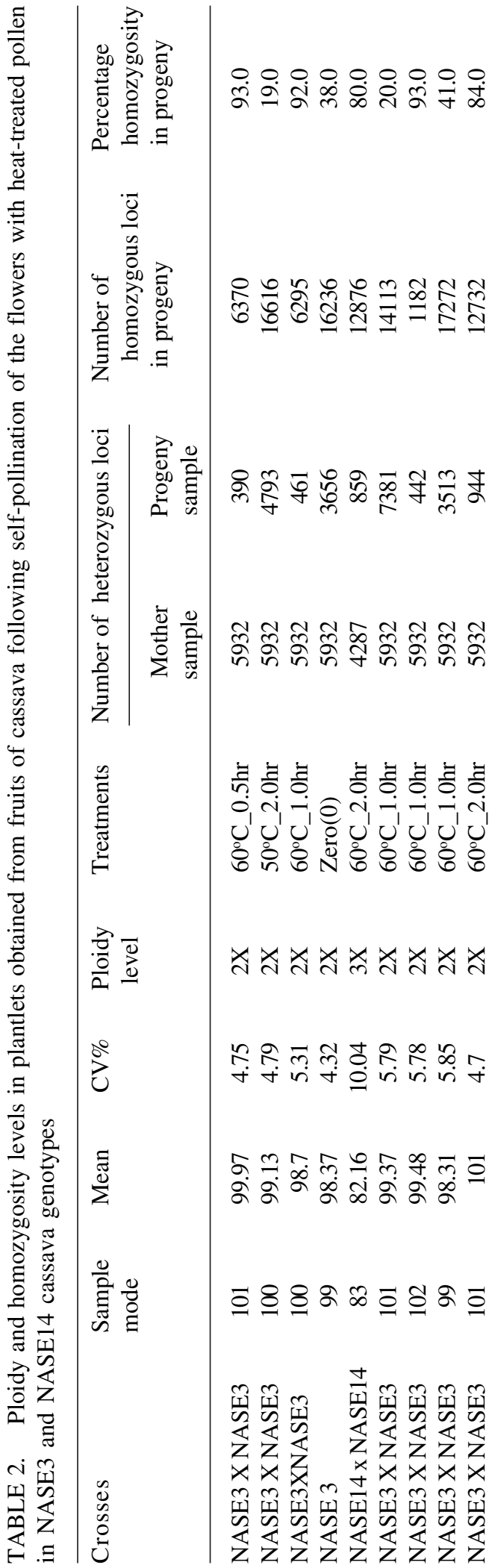

Plants of increased homozygosity of 92.093.0\% were recorded for NASE3 treatment of $60{ }^{\circ} \mathrm{C}$ for 0.5 and $1.0 \mathrm{hr}$ duration (Table 2). Plants were validated for homozygosity by analysing 22,618 SNPs and flow cytometry analyses, which showed variable homozygosity depending on the treatment ranging from $24.0-93.0 \%$ (Table 2).

Multiple embryonic structures observed led to production of multiple plantlets per embryo, in embryos from fresh pollen, and regeneration efficiency of embryos into plants was low in NASE14 as compared to NASE3 (data not shown).

Changes in the colour of embryogenic structures were observed from off-white to green after transfer to $16 / 8$ light/dark photoperiod for 56 days on half-strength basal MS medium with 0.09M sucrose (Fig. 5). After colour change, multiple embryoids were isolated (Fig. 5) and transferred to the same medium for plantlet regeneration, of which some of the regenerated plantlets developed yellow shoots (data not shown). These plantlets stopped growing and eventually died; while green shoots developed normally (Fig. 5) into whole plantlets and were hardened-off in a growth chamber, and transferred to the screen house (Fig. 6).

Ploidy and homozygosity of plantlets. Ploidy analyses revealed that most of the plant samples were diploid (2X), apart from NASE14 x NASE14 at $60^{\circ} \mathrm{C}$ for $2 \mathrm{hr}$, which had increased level 3 of homozygosity of 80.0\%; and NASE3 x NASE3 (at $60^{\circ} \mathrm{C}$ at 0.5 , 1.0 , and $2.0 \mathrm{hr}$ ) with increased levels of homozygosity to $93.0 \%$ (Table 2). Zygosity analyses in the mother and progeny samples, showed increased homozygosity at varying degrees of $19.0 \%$ at $50{ }^{\circ} \mathrm{C}$ for $2.0 \mathrm{hr}$ to $93 \%$ at $60{ }^{\circ} \mathrm{C}$ for $1.0 \mathrm{hr}$ (Table 2).

\section{DISCUSSION}

Pollen germination and pollen tube growth. High temperature treatments in cassava reduced pollen germination and pollen tube 
growth, in vitro and in vivo, and these processes were completely inhibited at $60{ }^{\circ} \mathrm{C}$ (Table 1), indicating possible inhibition of fertilisation at this or higher temperatures. Inhibition of germination and pollen tube growth was previously reported under high temperatures in almond (Prunus dulcis) (Sorkheh et al., 2018) and common hazel

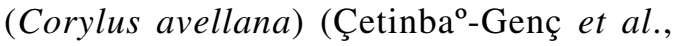
2019). Accordingly, high temperatures caused destructive effects to the pollen by depolymerisation of actin cytoskeleton by preventing production of a functional pollen tube (Çetinba ${ }^{\circ}-G e n c ̧$ et al., 2019). The development of pollen tubes is essential because they are the only passage for two sperm cells to reach the embryo sac for effecting fertilisation. As such, pollen germination and pollen tube growth analyses are critical for understanding plant reproduction (Obermeyer and Feijó, 2017). In this study, self-pollination with heat-treated and fresh pollen revealed the presence of developed pollen tubes reaching the embryo sac region at 1 DAP for fresh pollen, as was previously observed in Manihot mill species by de Jesus et al. (2015). For heat-treated pollen, germination was observed only on the stigma in both NASE3 and NASE14 genotypes, though no penetration in the nucellar beak or embryo sac region was observed, except for NASE $360^{\circ} \mathrm{C}$ at 3 DAP, whose pollen entered the nucellar beak but not the embryo sac region.

Stimulating the division of the egg cell without fertilisation, and thus inducing parthenocarpic embryo development in plants, can be achieved using heat-treated pollen (Winton and Einspahr, 1968) and this was observed in our study (Fig. 6D). A similar observation was made in pollen grains of Brassica juncea exposed to high temperature (45, 60 and $75^{\circ} \mathrm{C}$ for $4-24 \mathrm{hr}$ ), in which pollen germination and pollen tube growth induced parthenocarpy (Rao et al., 1992). Further studies are needed to understand biochemical and/or physiological changes that occur in cassava pollen when subjected to high temperatures, leading to failure of pollen tube to reach the embryosac and archiving no fertilisation in cassava. Any impact of temperature is not expected to depend on selfversus cross-pollination because the mode of pollination in cassava was recently shown to be irrelevant for pollen tube growth and development (Ramos Abril et al., 2019). Failure of cassava pollen tube to reach the embryosac under this study is similar to previous observations in maize in which isolated pollen lost its fertilisation abilities when subjected to heat treatment of $40{ }^{\circ} \mathrm{C}$ for $4 \mathrm{~h}$ (Dupuis and Dumas, 1990). Also, heat stress treatment resulted in the reduction of pollen viability of faba bean (Kumar et al., 2016) and low germination rate and poor pollen tube growth of pedunculate oak (Sever et al., 2012). Moreover, after 6 days of heat stress, the pollen viability and germination of flax was adversely affected (Cross et al., 2003). Steps in pollen tube development in cassava shows a major slowdown in pollen tube entry into the embryosac (Ramos Abril et al., 2019) and how this development slowdown may get further decelerated due to heat stress on the pollen is unclear. Studies in Arabidopsis thaliana delineate four stages of pollen tube development (Kandasamy et al., 1994) and a related pattern of pollen tube development occurs in cassava (Ramos Abril et al., 2019). Essentially, the negative effect of heat stress could be felt at any of the phases of pollen tube development, although such effects in angiosperms' sexual reproduction are generally higher in earlier than later stages of pollen tube development (Hedhly, 2011; Snider and Oosterhuis, 2011; Muller and Rieu 2016; Raja et al., 2019).

Embryo rescue and fruit set. We present a new approach for embryo rescue in cassava in which, instead of traditionally isolating embryos, individual ovary carpels (containing one ovule each) can be cultured. This approach makes it possible to successfully 
culture immature zygotic embryos before they are fully formed, while supporting the development of the proembryos inside the ovules by exogenous supply of nutrients from the culture medium and avoiding their physical damage in the handling process. This method of culture, in combination with an optimised rich culture medium composition sequence under this study, allowed rescuing embryos at very early stages of development collected at 14 DAP. Previously, cassava embryos could only be rescued not earlier that 28 DAP (Yan et al., 2014), indicating 50\% improved efficiency in embryo rescue under our study.

Embryo rescue techniques are essential for supporting juvenile embryos that would otherwise not progress under in vivo development conditions; as such, successful embryo culture technique is dependent on both stage of development of the embryo and culture medium composition (Shahzad et al., 2017).

The observed reduction in fruit set and high fruit abortion in the two cassava genotypes following self-pollination with heat-treated pollen, was probably due to the presence of poorly developed or incompatible endosperm and early inhibition of embryo development. This was evidenced by the histological examinations done in this study, showing high degeneration of embryo sac region. Although not confirmed in our studies, it is also likely that the aborted fruits had fragile haploid embryos because of the numerous deleterious alleles fixed by clonal propagation (Ramu et al., 2017). In such cases, embryo rescue techniques are helpful in inducing the development of haploid embryos, by isolating and culturing whole ovaries, ovules or embryos (Dwivedi et al., 2015). This procedure was initially applied in Phaseolus vulgaris and Fagopyrum tataricum, which later developed to mature plants (Schopfer and Noecker, 1943). Previously, we employed a similar technique following self-pollination with irradiated pollen in cassava (Buttibwa et al., 2015), which allowed the regeneration of diploid cassava plants. Embryo rescue medium provides nutrients needed for embryo development (Mobini et al., 2015), which together with the stage of embryo at rescue may determine the success of embryo into maturation (Sharma et al., 1996).

In our study, embryos with high vigour were able to develop into plantlets, but those that were white in colour did not develop further, indicating that poorly developed embryos are a dead end to plant regeneration. Similarly, Relan (2017) showed that a small and poorly developed $(<0.5 \mathrm{~mm})$ durum wheat haploid embryos failed to germinate, whereas those with a defined structure and vigorous appearance; and about $2 \mathrm{~mm}$ in length had high germination capacity. Therefore, well developed embryos in cassava can be rescued and plants successfully regenerated earlier than usually practiced.

Polyembryony. We observed a high rate of multiple embryo formation (polyembryony) from a single ovule in cassava self-pollinated with fresh pollen, indicating that polyembryony may be a norm of cassava's sexual reproductive systems (Fig. 5A, B and C). Previously, polyembryony was found at a frequency of $1 \%$ in the hybrid of cassava with Manihot oligantha produced via outcrossing, in which the extent of polyembryony was increased by polyploidisation (Nassar, 2006a, b; 2010). In cassava, whether polyembryony is more pronounced under cross or self-pollination is not clear. In many plants with polyembryonic reproduction, all the embryos, except one are usually aborted, creating an opportunity for reproductive compensation within ovules (Sorensen, 1982; Porcher and Lande, 2005a,b). Cassava is predominantly outcrossing; however, there is also no evidence of self-incompatibility, implying that in nature, self-pollinations may yield viable botanical seed and associated inbreeding depression (Westwood, 1990; Rojas et al., 2009; Ramos Abril et al., 2019). In contrast, possible low embryo survival in selfpollinations together with observed 
polyembryony, may allow post fertilisation embryo abortion and selection, which may constitute a mechanism of maintaining heterozygosity in cassava, similar to observations in conifers (Sorensen, 1982; Williams and Savolainen, 1996).

The emergence of polyembryos in cassava may also be induced or enhanced by culture conditions. For example, in grapevines (Vitis vinifera), 4-5 times increase in vitamin and hormone levels in the culture medium increased polyembryony from 20.0 to $85.7 \%$ (Tsolova and Atanassov, 1994). In a fern, Pteris tripartite $\mathrm{Sw}, \mathrm{BAP}$ cytokinin concentrations at $3 \mathrm{mg} \mathrm{L}^{-1}$ in MS medium significantly induced more polyembryony than lower concentrations (Ravi, 2016). In wheat, polyembryony was attributed to high concentrations of sucrose in the medium (Altamura et al., 2016). In our study, we used strong auxins such as 2, 4-D at $5 \mathrm{mg} \mathrm{L}^{-1}$, but whether or not this may account for the observed polyembryony in cassava under culture remains to be verified.

Homozygosity and ploidy. Using 22,618 SNP markers to analyse zygosity, plantlets rescued from embryos at 21 DAP indicated increased homozygosity of up to $93.0 \%$. Increased levels of homozygosity of up to $98.0 \%$ was previously observed in maize (Asker and Jerling, 1992), and up to $68.0 \%$ in cassava progeny obtained from flowers pollinated with irradiated pollen (Buttibwa et al., 2015). In the current study, diploid embryos could have been due to spontaneous doubling of chromosomes in the induced embryo from the egg cell, or from fusion of two haploid cells in the embryo sac (either the synergids, or the antipodals, or the polar nuclei) (Munné et al., 1995). Either way, increased homozysgosity observed under this study implies that any deleterious alleles could be eliminated from cassava during double haploid breeding. Cassava is predominantly outcrossing in nature, yet frequently propagated by vegetative means, which implies that the norm of heterozygosity has indeed fixed deleterious alleles and shifted the mutational burden toward common variants (Ramu et al., 2017). Indeed, in cassava, deleterious mutations are the main inherent constraint associated with inbreeding depression (Ceballos et al., 2016; de Freitas et al., 2016; Ramu et al., 2017).

Even in elite cassava accessions, the effects of inbreeding depression are extremely severe in which a single generation of inbreeding may lead to over $60.0 \%$ decrease in fresh root yield hence the need for the homozygous lines in cassava breeding (de Freitas et al., 2016). Therefore, the observed increased homozygosis should facilitate purging of deleterious alleles that for long are masked in by heterozygosity and facilitate pure line breeding in cassava (Ramu et al., 2017).

\section{CONCLUSION}

This study highlights the effect of heat-treated pollen from cassava in self-pollinations and the associated high incidence of polyembryony and parthenocarpy in the development of doubled haploids. Self-pollination with heat-treated pollen and the technique of embryo rescue allowed for recovery of plants in cassava that can be further developed into haploids, which provides opportunities for double-haploid (DH) plants.

Results of this study indicate successful fruit set, induced by heated cassava pollen, and increased homozygosity in cassava embryos, following pollination of cassava female flowers with heat-treated pollen. For the first time, cassava proembryos were regenerated from ovules rescued 14 DAP. Until now, this was possible only earliest 28 DAP, indicating improved efficiency of our embryo rescue procedure. Limited studies show a general recalcitrance in respect to development of DH protocols via both gynogenesis and androgenesis in cassava in comparison to other crops whose $\mathrm{DH}$ protocols have undergone rigorous optimisation over decades in numerous laboratories. Increased homozygosity in cassava observed under this 
study can be exploited in eliminating disadvantageous alleles that have long been hidden in their heterozygous stare. Overall, the 'unit of success' reported in this study contributes to efforts towards development of $\mathrm{DH}$ cassava for the enhancement of cassava breeding.

\section{ACKNOWLEDGMENT}

This work was funded by the International Centre for Tropical Agriculture (CIAT) through Grant 14 ID no. OPPGD1483 from the Bill and Melinda Gates Foundation. We thank Mr. Moses Nyine of the International Institute of Tropical Agriculture (IITA-Uganda) for technical assistance in ploidy analysis, $\mathrm{Mr}$. Osingada Francis (National Crops Resources Research Institute, NaCRRI) for DNA extraction, and Mr. Kisekka Magidu of College of Veterinary Medicine Animal Resources and Biosecurity (Makerere University, Uganda) for providing technical assistance in processing samples for the histology analysis. We are grateful to Dr. Henry Wagaba (NaCRRI) for helpful discussions and comments on the earlier versions of this manuscript.

\section{REFERENCES}

Abdi, H. 2007. The Kendall rank correlation coefficient. In: Salkind, N.J. (Ed.). Encyclopedia of Measurement and Statistics. Sage, Thousand Oaks, CA.

Altamura, M.M, Della Rovere, F., Fattorini, L., D'Angeli, S. and Falasca, G. 2016. Recent advances on genetic and physiological bases of in vitro somatic embryo formation. In: German, M.A. and Lamardi, M. (Eds.). In vitro embryogenesis in higher plants. Springer, New York. pp. 47-85.

Asker, S. and Jerling, L. 1992. Apomixis in plants. $1^{\text {st }}$ Edition, CRC press.

Baguma, J., Mukasa, S., Kawuki, R., Tugume, A,K., Buttibwa, M., Nalela, P., Eyokia, M., Oshaba, B., Ceballos, H., Lentini, Z. and Baguma, Y. 2019. Fruit set and plant regeneration in cassava following interspecific pollination with castor bean. African Crop Science Journal 27(1):99118.

Bohanec, B. 2009. Doubled haploids via gynogenesis. In: Touraev, A., Forster, B.P., and Jain, S.M. (Eds.). Advances in Haploid Production in Higher Plants. Springer, Dordrecht. pp. 35-46.

Bohanec, B., Jakše, M., Ihan, A. and Javornik, B. 1995. Studies of gynogenesis in onion (Allium cepa L.): induction procedures and genetic analysis of regenerants. Plant Science 104(2):215-224.

Bradbury, P.J., Zhang, Z., Kroon, D.E., Casstevens, T.M., Ramdoss, Y. and Buckler, E.S. 2007. TASSEL: software for association mapping of complex traits in diverse samples. Bioinformatics 23(19):2633-2635.

Brewbaker, J.L. and Kwack, B.H. 1963. The essential role of calcium ion in pollen germination and pollen tube growth. American Journal of Botany 50(9):859865.

Buttibwa, M., Kawuki, R.S., Tugume, A.K., Akol, J., Magambo, S., Apio, H., A., Heberle-Bors, E., Wedzony, M., Ceballos, H., Hershey, C. and Baguma, Y. 2015. In vitro embryo rescue and plant regeneration following self-pollination with irradiated pollen in cassava (Manihot esculenta Crantz). African Journal of Biotechnology 14(27):2191-2201.

Ceballos, H., Kawuki, R.S., Gracen, V.E., Yencho, G.C. and Hershey, C.H. 2015. Conventional breeding, marker-assisted selection, genomic selection and inbreeding in clonally propagated crops: a case study for cassava. Theoretical and Applied Genetics 128(9):647-1667.

Ceballos, H., Pérez, J.C., Barandica, O.J., Lenis, J.I., Morante, N., Calle, F., Pino, L. and Hershey, C.H. 2016. Cassava Breeding I: The Value of Breeding Value. Frontiers in Plant Science 7:1227.

Çetinba ${ }^{\circ}$-Genç, A., Cai, G., Vardar, F. and Ünal, M. 2019. Differential effects of low and 
high temperature stress on pollen germination and tube length of hazelnut (Corylus avellana L.) genotypes. Scientia Horticulturae 255:61-69.

Chen, J.-F., Cui, L., Malik, A.A. and Mbira, K.G. 2011. In vitro haploid and dihaploid production via unfertilized ovule culture. Plant Cell, Tissue and Organ Culture 104(3):311-319.

Cross, R.H., McKay, S.A.B., McHughen, A.G. and Bonham, S.P.C. 2003. Heat-stress effects on reproduction and seed set in Linum usitatissimum L. (flax). Plant, Cell and Environment 26(7):1013-1020.

de Freitas, J.P.X., Santos, V.S. and de Oliveira, E.J. 2016. Inbreeding depression in cassava for productive traits. Euphytica 209:137-145.

de Jesus Vieira, L., de Santana, J.R.F., Alves, A.A.C., da Silva Ledo, C.A. and Souza, F.V.D. 2015. Use of aniline blue stain to observing pollen tubes development in different Manihot Mill. species. African Journal of Agricultural Research 10(15):1805-1809.

Dupuis, I. and Dumas, C. 1990. Influence of temperature stress on in vitro fertilization and heat shock protein synthesis in maize (Zea mays L.) reproductive tissues. Plant Physiololgy 94(2):665-670.

Dwivedi, S.L., Britt, A.B., Tripathi, L., Sharma, S., Upadhyaya, H.D. and Ortiz, R. 2015. Haploids: constraints and opportunities in plant breeding. Biotechnology Advances 33(6):812-829.

Elshire, R.J., Glaubitz, J.C., Sun, Q., Poland, J.A., Kawamoto, K., Buckler, E.S. and Mitchell, S.E. 2011. A robust, simple genotyping-by-sequencing (GBS) approach for high diversity species. PLOS ONE 6(5): e19379.

Foroughi-Wehr, B. and Wenzel, G. 1993. Andro-and parthenogenesis. In: Hayward, M.D., Bosemark, N.O., Romagosa, I., and Cerezo, M. (Eds.) Plant Breeding. Plant Breeding Series. Springer, Dordrecht. pp 261-277.
Forster, B.P., Heberle-Bors, E., Kasha, K.J. and Touraev, A. 2007. The resurgence of haploids in higher plants. Trends in Plant Sciences 12(8):368-375.

Fukuda, W.M.G., de Oliveira, S. and Iglesias, C. 2002. Cassava breeding. Crop Breeding and Applied Biotechnology 2:617-638.

Germana, M.A. 2011a. Anther culture for haploid and doubled haploid production. Plant Cell, Tissue and Organ Culture 104:283-300.

Germana, M.A. 2011b. Gametic embryogenesis and haploid technology as valuable support to plant breeding. Plant Cell Reports 30(5):839-857.

Godbole, M. and Murthy, H.N. 2012. Parthenogenetic haploid plants using gamma irradiated pollen in snapmelon (Cucumis melo var. momordica). Plant Cell, Tissue and Organ Culture 109:167170.

Hahn, S.K., Terry, E.R. and Leuschner, K. 1980. Breeding cassava for resistance to cassava mosaic disease. Euphytica 29(3):673-683.

Hamblin, M. and Rabbi, I.Y. 2014. The effects of restriction-enzyme choice on properties of genotyping-by-sequencing libraries: A study in cassava. Crop Science 54(6):26032608.

Hedhly, A. 2011. Sensitivity of flowering plant gametophytes to temperature fluctuations. Environmental and Experimental Botany 74:9-16.

Howeler, R., Lutaladio, N. and Thomas, G. 2013. Save and grow: cassava - A guide to sustainable production intensification. FAO, Rome, Italy. ISBN 978-92-5-107641-5

Kandasamy, M.K., Nasrallah, J.B. and Nasrallah, M.E. 1994. Pollen-pistil interactions and developmental regulation of pollen tube growth in Arabidopsis. Development 120:3405-3418.

Kawano, K. 2003. Thirty years of cassava breeding for productivity-biological and social factors for success. Crop Science 43(4):1325-1335. 
Kumar, O. and Choudhary, M. 2020. Double Haploid: An overview. International Journal of Current Microbiology and Appled Science 9(1):1012-1029.

Kumar, R., Singh, A.K., Lavania, D., Siddiqui, M.H., Al-Whaibi, M.H. and Grover, A. 2016. Expression analysis of ClpB/Hsp100 gene in faba bean (Vicia faba L.) plants in response to heat stress. Saudi Journal of Biological Science 23(2):243-247.

Kundu, M., Dubey, A., Srivastav, M., Malik, S. and Singh, B. 2014. Effect of gamma ray irradiation and cryopreservation on pollen stainability, in vitro germination, and fruit set in Citrus. Turkish Journal of Biology 38:1-9.

Lawson, L., Winton, D. and Einspahr, W. 1968. The Use of Heat-Treated Pollen for Aspen Haploid Production. Forest Science 14(4):406-407.

Lentini, Z., González, Á., Tabares, E., Buitrago, M.E. and Wêdzony, M. 2020a. Studies on gynogenesis induction in cassava (Manihot esculenta Crantz) unpollinated ovule culture. Frontiers in Plant Science 11:365.

Lentini, Z., Restrepo, G., Buitrago, M.E. and Tabares, E. 2020b. Protocol for rescuing young cassava embryos. Frontiers in Plant Science 11:522.

Michalik, B., Adamus, A. and Nowak, E. 2000. Gynogenesis in Polish onion cultivars. Journal of Plant Physiology 156(2):211216.

Mishra, V.K. and Goswami, R. 2014. Haploid production in higher plants. International Journal of Chemistry and Biological Science 1(1):25-45.

Mobini, S.H., Lulsdorf, M., Warkentin, T.D. and Vandenberg, A. 2015. Plant growth regulators improve in vitro flowering and rapid generation advancement in lentil and faba bean. In Vitro Cell Developmental Biology in Plants 51:71-79.

Munné, S., Alikani, M., Tomkin, G., Grifo, J. and Cohen, J. 1995. Embryo morphology, developmental rates, and maternal age are correlated with chromosome abnormalities. Fertility and Sterility 64(2):382-391.

Murashige, T. and Skoog, F. 1962. A revised medium for rapid growth and bio assays with tobacco tissue cultures. Physiologie Plantarum 15(3):473-497.

Murovec, J. and Bohanec, B. 2012. Haploids and doubled haploids in plant breeding. In: Maluszynski, M., Kasha, K.J., Forster, B.P. and Szarejko, I. (Eds.). Doubled Haploid Production in Crop Plants. Springer, Dordrecht.

Müller, F. and Rieu, I. 2016. Acclimation to high temperature during pollen development. Plant Reproduction 29(12):107-118.

Nassar, N.M.A. 2006a. Chromosome doubling induces apomixis in a cassava $\mathrm{x}$ Manihot anomala hybrid. Hereditas 143:246-248.

Nassar, N.M.A. 2006b. The synthesis of a new cassava-derived species, Manihot vieiri Nassar. Genetics and Molecular Resarch 5(3):536-541.

Nassar, N. and Ortiz, R. 2010. Breeding cassava to feed the poor. Scientific American 302(5):78-85.

Nassar, N.M.A., Hashimoto, D.Y. and Ribeiro, D.G. 2010. Genetic, embryonic and anatomical study of an interspecific cassava hybrid. Genetics and Molecular Research 9(1):532-538.

Obiri, J.A.F., Driver, M.F., Onyekwelu, J.C., Akpoko J.G., Ramasawmy, B. and DraméYaye, A. 2017. Agricultural risk management in Africa - A contextualized manual for tertiary institutions and development practioners. ANAFE, Nairobi, Kenya.

Obermeyer, G. and Feijó, J. 2017. Pollen tubes and tip growth of biophysics and tipomics. In: Bermeyer, G. and Feijó, J. (Eds.). Pollen Tip Growth, Springer, pp. 3-10.

Ochatt, S., Patat-Ochatt, E. and Moessner, A. 2011. Ploidy level determination within the context of in vitro breeding. Plant Cell, Tissue and Organ Culture 104:329-341. 
Okogbenin, E., Setter, T.L., Ferguson, M., Mutegi, R., Ceballos, H., Olasanmi, B. and Fregene, M. 2013. Phenotypic approaches to drought in cassava. Frontiers in Physiology 4(93):1-15.

Patil, B.L., Legg, J., Kanju, E. and Fauquet, C.M. 2015. Cassava brown streak disease: a threat to food security in Africa. Journal of General Virology 96(5):956-968.

Perera, P., Ordoñez, C., Lopez-Lavalle, L.B. and Dedicova, B. 2014. A milestone in the doubled haploid pathway of cassava. Protoplasma 251(1):233-246.

Piosik, L., Zenkteler, E. and Zenkteler, M. 2016. Development of haploid embryos and plants of Lactuca sativa induced by distant pollination with Helianthus annuus and $H$. tuberosus. Euphytica 208(3):439-451.

Ponitka, A., Slusarkiewicz-Jarzina, A., Wedzony, M., Marcinska, I., Wozny, J. and Wozna, J. 1999. The influence of various in vitro culture conditions on androgenetic embryo induction and plant regeneration from hexaploid triticale (x Triticosecale Wittm.). Journal of Applied Genetics 40(3):165-174.

Porcher, E. and Lande, R. 2005a. Reproductive compensation in the evolution of plant mating systems. New Phytologist 166(2):673-684.

Porcher, E. and Lande, R. 2005b. The evolution of self-fertilization and inbreeding depression under pollen discounting and pollen limitation. Journal of Evolutionary Biology 18(3):497-508.

Raja, M.M., Vijayalakshmi, G., Naik, M.L., Basha, P.O., Sergeant, K., Hausman, J.F., and Khan, P.S.S.V. 2019. Pollen development and function under heat stress: from effects to responses. Acta Physiologiae Plantarum 41(4):47

Ramos Abril, L.N., Pineda, L., Wasek, I., Wedzony, M. and Ceballos, H. 2019. Reproductive biology in cassava: stigma receptivity and pollen tube growth. Communicative and Integrative Biology 12(1):96-111.
Ramu, P., Esuma, W., Kawuki, R., Rabbi, I.Y., Egesi, C., Bredeson, J.V., Bart, R.S., Verma, J., Buckler, E.S. and Lu, F. 2017. Cassava haplotype map highlights fixation of deleterious mutations during clonal propagation. Nature Genetics 49(6):959963.

Rao, G.U. Jain, A. and Shivanna, K.R. 1992. Effects of high temperature stress on Brassica pollen: Viability, germination and ability to set fruits and seeds. Annals of Botany 69(3):193-198.

Ravi, B.X. 2016. In vitro polyembryony induction in a critically endangered fern, Pteris tripartita Sw. Asian Pacific Journal of Reproduction 5(4):345-350

Relan, A. 2017. Genetics of size of haploid embryo induced through chromosome elimination-mediated approach of DH breeding in Wheat and standardization of protocol for enhancing its regenerability. Cskhpkv, Palampur., M.Sc. Thesis. Pradesh Agriculture University, Palampur, India. 135pp.

Rojas, M.C., Pérez J.C., Ceballos, H., Baena, D., Morante, N. and Calle, F. 2009. Introduction of inbreeding and analysis of inbreeding depression in eight $\mathrm{S} 1$ cassava families. Crop Science 49(2):543-548.

San, L.H. and Gelebart, P. 1986. Production of gynogenetic haploids. In: Cell culture and somatic cell genetics of plants: Plant regeneration and genetic variability, Vol. 3, Vasil, I. (Ed.). pp. 305-322, Academic Press, Cambridge.

Schopfer, W.H. and Noecker, N.L. 1943. Plants and vitamins. A New Series of Plant Science Books, Vol. 11. Chronica botanica Company, London. 394pp.

Sever, K., Škvorc, •., Bogdan, S., Franjiæ, J., Krstonošiæ, D., Aleškoviæ, I., Kereša, S., Fruk, G. and Jemriæ, T. 2012. In vitro pollen germination and pollen tube growth differences among Quercus robur L. clones in response to meteorological conditions. Grana 51(1):25-34. 
Shahzad, A., Sharma, S., Parveen, S., Saeed, T., Shaheen, A., Akhtar, R., Yadav, V., Upadhyay, A. and Ahmad, Z. 2017. Historical perspective and basic principles of plant tissue culture. In: Abdin, M.Z., Kamaluddin, U.K., and Ali, A. (Eds.) Plant biotechnology: Principles and Applications. Springer, Singapore. pp. 136.

Sharma, D., Kaur, R. and Kumar, K. 1996. Embryo rescue in plants - a review. Euphytica 89:325-337.

Shumilina, D., Kornyukhin, D., Domblides, E., Soldatenko, A. and Artemyeva, A. 2020. Effects of Genotype and Culture Conditions on Microspore Embryogenesis and Plant Regeneration in Brassica rapa ssp. Rapa L. Plants 9(2):278.

Snider, J.L. and Oosterhuis, D.M. 2011. How does timing, duration and severity of heat stress influence pollen-pistil interactions in angiosperms? Plant Signaling and Behavior 6:(7)930-933;

Sorensen, F.C. 1982. The roles of polyembryony and embryo viability in the genetic system of conifers. Evolution 36(4):725-733.

Sorkheh, K., Azimkhani, R., Mehri, N., Chaleshtori, M.H., Halász, J., Ercisli, S. and Koubouris, G.C. 2018. Interactive effects of temperature and genotype on almond (Prunus dulcis L.) pollen germination and tube length. Scientific Horticulturae 227:162-168.

Stamp, J.A. and Henshaw, G.G. 1987. Secondary somatic embryogenesis and plant regeneration in cassava. Plant Cell, Tissue and Org Culture 10:227-233.

Stupak, M. 2008. Improving protein content in cassava storage roots. ETH Zurich, Germany, Universitat Karlsruhe (TH), Germany. pp. 2-95.

Tsolova, V. and Atanassov, A. 1994. Induction of polyembryony and secondary embryogenesis in culture for embryo rescue of stenospermocarpic genotypes of Vitis vinifera L. Vitis 33:55-56.
Verzani, J. 2018. Using R for introductory statistics: Chapman and Hall, CRC.

Villasenor, J.A.V. and Estrada, E.G. 2009. A generalization of Shapiro-Wilk's test for multivariate normality. Communication Statistics and Theoretical Methods 38(11):1870-1883.

Wang, W., Feng, B., Xiao, J., Xia, Z., Zhou, X., Li, P., Zhang, W., Wang, Y., Møller, B.L., Zhang, P., Luo, M., Xiao, G., Liu, J., Yang, J., Chen, S., Rabinowicz, P.D., Chen, X., Zhang, H., Ceballos, H., Lou, Q., Zou, M., Carvalho, L.J.C.B., Zeng, C., Xia, J., Sun, S., Fu, Y., Wang, H., Lu, C., Ruan, M., Zhou, S., Wu, Z., Liu, H., Kannangara, R.M., Jørgensen, K., Neale, R.L., Bonde, M., Heinz, N., Zhu, W., Wang, S., Zhang, Y., Pan, K., Wen, M., Ma, P., Li, Z., Hu, M., Liao, W., Hu, W., Zhang, S., Pei, J., Guo, A., Guo, J., Zhang, J., Zhang, Z., Ye, J., Ou, W., Ma, Y., Liu, X., Tallon, L.J., Galens, K., Ott, S., Huang, J., Xue, J., An, F., Yao, Q., Lu, X., Wu, J., You, F.M., Chen, M., Hu, S., Fregene, M. and Lo, L.A.B. 2014. Cassava genome from a wild ancestor to cultivated varieties. Nature Communications 5(5110):1-9.

Wang, C., Lentini, Z., Tabares, E., Quintero, M., Ceballos, H., Dedicova, B., Sautter, C., Olaya, C. and Zhang, P. 2011. Microsporogenesis and pollen formation in cassava. Biologie Plantarum 55(3):469478.

Wêdzony, M., Forster, B.P., ' ur, I., Golemiec, E., Szechyñska-Hebda, M., Dubas, E. and Gotêbiowska, G. 2009. Progress in doubled haploid technology in higher plants. In: Touraev, A., Forster, B.P., Jain, S.M (Eds.) Advances in haploid production in higher plants. Springer Netherlands. pp 1-33.

Westwood, N.N. 1990. Maintenance and storage: Clonal germplasm. In: Janick, J. (Ed.). Plant Breeding Reviews: The National Plant Germplasm System of the United States, Volume 7. John-Wiley and Sons, USA. pp. 111-128. 
Williams, C.G. and Savolainen, O. 1996. germplasm. Crop Science 50(6):2364Inbreeding Depression in Conifers: Implications for Breeding Strategy. Forest Science 42(1):102-117.

Winton, L.L. and Einspahr, D.W. 1968. The use of heat-treated pollen for aspen haploid production. Forest Science 14(4):406-407.

Yada, B., Tukamuhabwa, P., Alajo, A. and Mwanga, R. 2010. Morphological characterization of Ugandan sweetpotato 2371.

Yan, H., Lu, L., Alzate, A., Ceballos, H., Hershey, C., Chen, S. and Li, K. 2014. Fruit, seed and embryo development of different cassava (Manihot esculenta Crantz) genotypes and embryo rescue. African Journal of Biotechnology 13(14):1524-1528. 